\title{
The Impact of Environmental Regulation on Location's Choice of Cross-Border Mergers and Acquisitions*
}

\section{El impacto de la regulación medioambiental sobre la elección de la localización de las fusiones y adquisiciones transfronterizas}

\author{
Federico Carril-Caccia \\ Universidad de Deusto \\ Universidad de Granada \\ Juliette Milgram Baleix \\ Universidad de Granada
}

\begin{abstract}
This study contributes to the literature seeking to test the pollution haven's hypothesis (PHH), by focusing on the influence of environmental policy on the location's decision of cross-border mergers and acquisitions $(M \& A s)$. To this end, we estimate a gravity model using an original bilateral database for the extensive margin of M\&A among 34 developed and emerging countries during the period 1995-2015. Reached evidence confirms only part of the pessimist predictions. A more stringent environmental regulation would not boost outward M\&As to the extent that it originates from countries with relatively good institutional quality. In contrast, in countries with relatively high level of corruption, the laxer the environmental regulation, the higher the number of inward M\&As. However, reducing corruption can compensate the competitiveness losses associated with the compliance of a stricter environmental regulation.
\end{abstract}

Keywords: corruption, environmental stringency, pollution havens, $M \& A s$, gravity.

JEL Classification: F18, F21, F23, F64.

\section{Resumen}

El presente estudio se enmarca dentro de la literatura sobre la formación de paraísos de contaminación. En concreto, se analiza si la política medioambiental afecta a la decisión de localización de las fusiones y adquisiciones (FyA) transfronterizas. Para ello, estimamos un modelo de gravedad y explotamos una novedosa base de datos que recoge el margen extensivo de las FyA entre 34 países desarrollados y emergentes durante el periodo 1995-2015. La evidencia alcanzada confirma parcialmente las predicciones pesimistas: cuando se trata de un país con una calidad institucional relativamente alta, una regulación ambiental más estricta no fomentará un

* This work received support from Junta de Andalucía [SEJ 340]. Federico Carril-Caccia also thanks the financial support from Generalitat Valenciana [GV/2020/012]. Juliette Milgram also thanks the contribution of Ministerio de Ciencia, Innovación y Universidades through grant PGC2018-093506-B-I00. 
mayor número de FyA en el exterior. Por el contrario, en aquellos países en los que existe un nivel relativamente elevado de corrupción, una regulación medioambiental más laxa implicará un número mayor de FyA entrantes. No obstante, la reducción de la corrupción puede compensar la pérdida de competitividad asociada al cumplimiento de una regulación medioambiental más exigente.

Palabras clave: corrupción, exigencias medioambientales, paraísos de contaminación, FyA, gravedad.

Clasificación JEL: F18, F21, F23, F64.

\section{Introduction}

The Sustainable Development Goals adopted by all UN Member States in 2015 include a commitment to achieve 17 goals before 2030. One of the most challenging objective is to diminish emission of carbon dioxide substantially. Green-led growth is increasingly becoming the officially announced development strategy for a post-COVID-19 recovery. Obviously, this encompasses important adaptations in the production and consumption processes. To encourage these changes, a more stringent regulation appears indispensable (but not sufficient). Many countries had already taken this path but, even when considering countries with similar levels of development, the levels of strictness of environmental regulation differ widely among them. Figure 1 depicts the levels of the Environmental Policy Stringency (EPS) for 17 countries. On average, the policies have become tougher but the disparities remain high, echoing the fact that not all the countries jump to the green policies at the same rhythm.

\section{FIGURE 1}

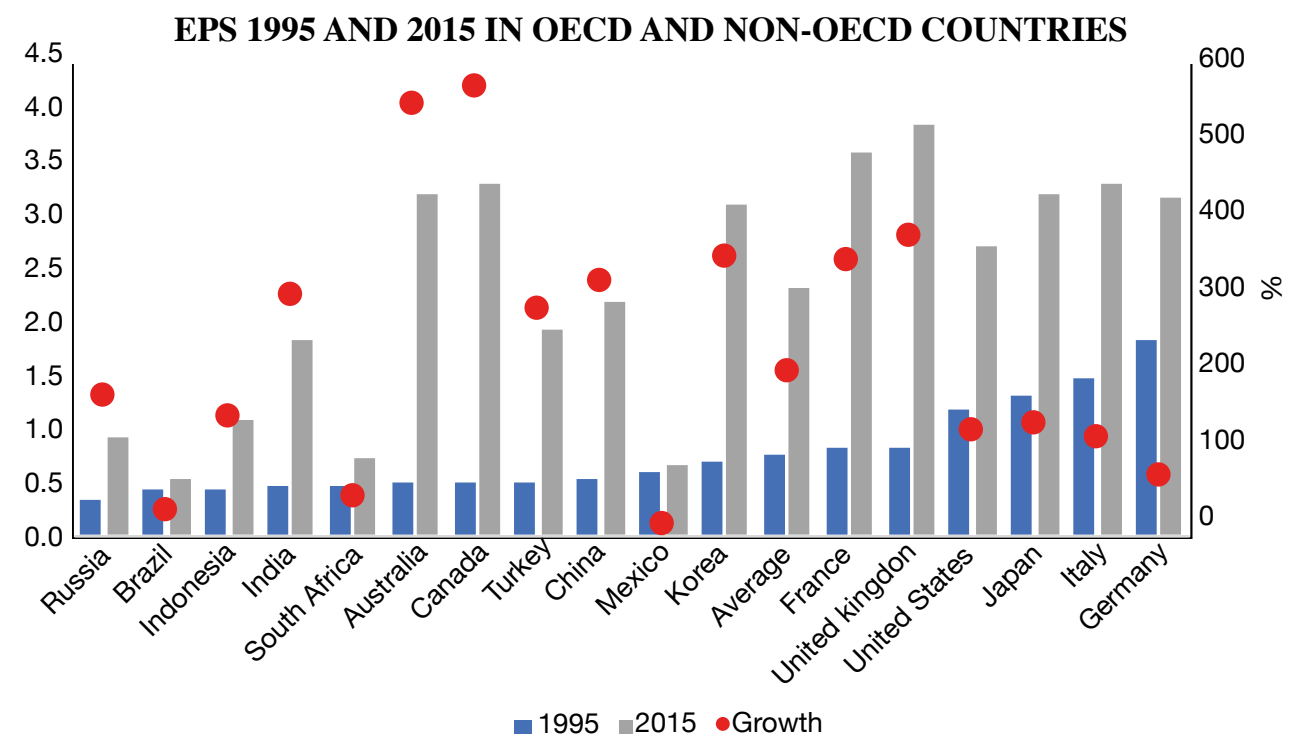

SOURCE: Authors' own elaboration based on OECD's EPS Index (Botta \& Koźluk, 2014). We present only the countries for which the EPS was available in both 1995 and 2015. 
In this regard, one heavily debated issue concerns whether this shift toward "green" policies would provoke a relocation of activity in countries with laxer regulation of the most polluting firms, a phenomenon known among academics as the pollution haven hypothesis (PHH). Many researchers have intended to check if such fear was supported by evidence. Results are far from unanimous, but tend to conclude that environmental measures usually do not increase sufficiently the costs to provoke per se massive relocations. The choice of locations would imply a trade-off between the advantages and disadvantages displayed by the distinct locations, compared with the firm's home country. Obviously, investors would take into consideration a wide range of factors such as the quality of institutions, market access, availability of capital and skilled labour, infrastructure and regulations, including environmental measures. Furthermore, more stringent environmental policies may even attract some multinationals (MNEs) if the location offers also a transparent and secured environment for doing business, or if "being green" is part of their strategy. In particular, countries with extremely lax environmental policies (usually developing countries) have not been all successful at attracting FDI, while countries with more stringent policies (developed and emerging countries) are those that attract more FDI worldwide. In this line, Figure 2 shows a weak but negative relationship between countries' ranking in terms of inward mergers and acquisitions (M\&As) and EPS; countries with stricter environmental policy are capable of attracting more M\&As projects than those that have a laxer policy.

\section{FIGURE 2}

\section{INWARD M\&AS RANKING AND EPS}

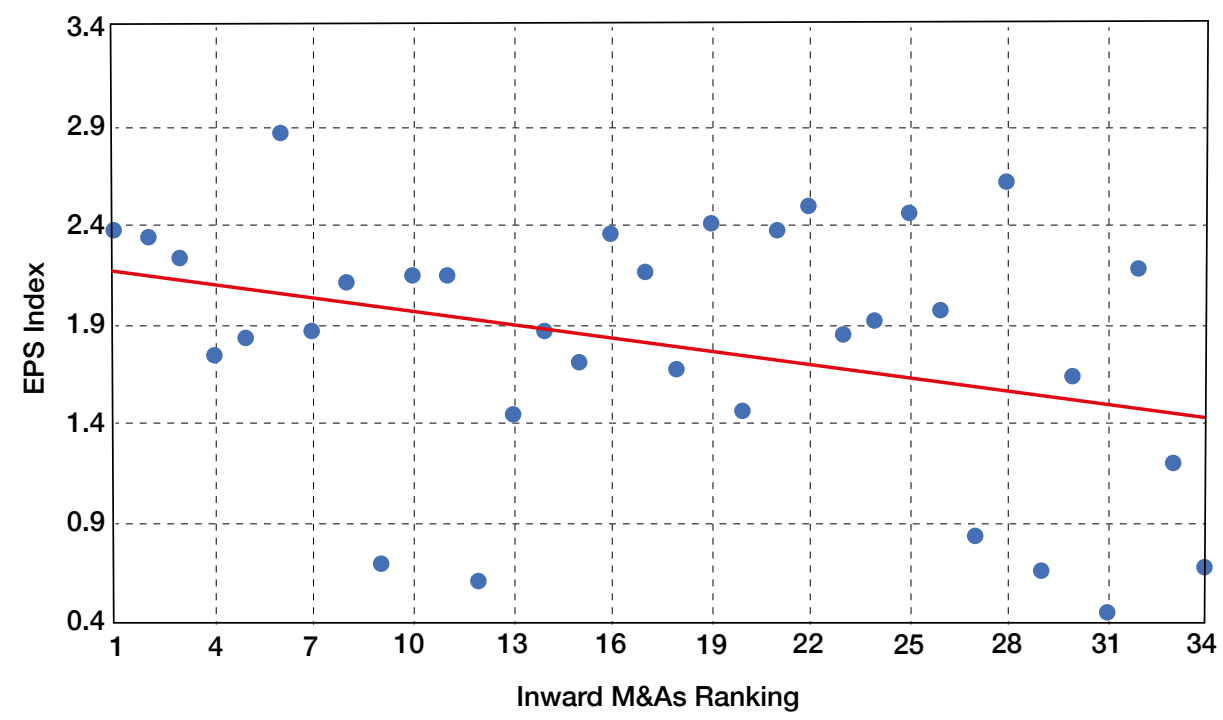

SOURCE: Authors' own elaboration based on the 1995-2015 average of OECD's EPS Index and Thomson Reuters' M\&As projects data. The ranking of countries is calculated by dividing the 1995-2015 average number of inward M\&As projects by GDP. 
This study examines if M\&A across nations are motivated by environmental stringency and business climate. To this end, we estimate a gravity model using an original bilateral database for the extensive margin of $\mathrm{M} \& \mathrm{~A}$, for projects originating from 100 countries and flying into 34 destination's countries, during the period 19952015. We test the two sides of the PHH: 1) Does a more stringent environmental policy push MNE to merge or acquire firms abroad? 2) Do countries with laxer environmental regulation attract cross-border M\&As? In addition, the present paper tests if the effect of environmental policy on M\&As is moderated by countries' institutional quality.

Previous research on the PHH has mostly focused on FDI flows without distinction of the mode of entry. The present article contributes to the literature by considering the case of cross-border M\&As. This mode of investment is becoming the most common. In the case of advanced nations, M\&As represent in 2016 more than 70\% of total inward and outward FDI capital flows. In developing nations, the prominence of M\&As has increased, but inward and outward FDI flows is still dominated by greenfield investment (Carril-Caccia \& Pavlova, 2018). Furthermore, the drivers of greenfield investment and M\&As are not completely homogeneous (see for instance Nocke \& Yeaple, 2007). In the particular case of the implications of environmental policy on FDI, greenfield projects often need to fulfill the latest environmental requirements, while M\&As may involve local firms that, due to grandfathering policies, do not need to adhere to the latest environmental regulation (Bialek \& Weichenrieder, 2015). Despite this fact, the case of M\&A has been overlooked in the FDI-environment literature. The exceptions are the studies of Leon-Gonzalez and Tole (2015) on M\&A in the mining industry and Bialek and Weichenrieder (2015) on German M\&A and greenfield investments. But the main drawback of these studies, and of most studies concerning the FDI-environment relationship, is that they do not account for multiple home and host and hence, reduce the possibility to explore the variations of regulations among countries.

We overcome these limitations by relying on a bilateral dataset with a wide sample of countries and a long period of analysis (1995-2015). Hence, we take into account both environmental measures in the home and possible host countries, allowing us to capture both push and pull factors. Another contribution of this study to the PHH literature is to take into account the link between corruption and environmental regulation; we explore whether MNEs could be willing to accept stricter environmental regulation in exchange of better business climate (or laxer regulation if business climate is worth).

To a certain extent, our results tend to confirm the PHH. On the one hand, we confirm that laxer environmental regulation could attract inward M\&As, especially in countries with highest levels of corruption. Nevertheless, our findings indicate that the implications of environmental policy on cross-border M\&As is conditioned on institutional quality. Reducing corruption can limit the deterrent effects of stricter environmental regulation on inward M\&As. On the other hand, to the extent that M\&As usually originate from countries where quality of institutions (proxied by 
lack of corruption) is relatively high, we reject the hypothesis that more stringent policies would incentive domestic firms to invest abroad through M\&As.

The following section provides a brief literature review on the FDI-environment relationship. Section 3 explains the empirical strategy and Section 4 discusses the results. Finally, the article ends with some concluding remarks.

\section{Literature review}

According to the $\mathrm{PHH}$, in response to a shift toward more stringent environmental policy and, in order to maximise profits, firms would be pulled to relocate in countries with looser environmental regulation. Hence, countries with lax environmental regulations would acquire comparative advantage, in particular in polluting industries (Pearson, 1987; Baumol \& Oates, 1988). Accordingly, weak environmental regulations could enhance incoming FDI.

The first generation of studies that intended to test the $\mathrm{PHH}$, failed to find conclusive results (see Cole et al. 2017) due to several limitations. Indeed, most of these studies were conducted on country or industry basis with aggregated FDI. Focusing on a specific host country obviates the alternative locations, while separating industries according to their pollution intensity can lead to biased results due to other industry specific trends.

This lack of robust evidence gave rise to a new generation of empirical models intending to overpass the methodological challenges that make difficult to capture the effect of environmental measures on FDI, while other authors have drawn the attention to other mechanisms that could counteract the rationale underlying the PHH. In particular, some authors have challenged the idea that investors would consider stringent environmental regulation as harmful. In contrast, they argue that some MNEs may consider environmental strictness as beneficial. Tougher policies regarding environment may induce several greening transfers both of environmentfriendly technology (Gallagher \& Zarsky, 2007) and management practices (Poelhekke \& Van der Ploeg, 2015; Jin et al., 2019). Hence, MNE could upgrade local environmental standards contributing to a positive "pollution halo" effect. ${ }^{1}$ Zugravu-Soilita (2017) advocates that the overall result may depend on the capital or skilled level abundance of countries along with the stringency of the environmental policy. Given the growing demand for environmentally friendly products and services, firms may also be interested in being the first in accessing environmentally sensitive consumers, located in markets with stricter environmental regulations in order to obtain price premiums, hence leading to a "win-win" situation (Rivera \& Oh, 2013). Moreover, several theoretical models have considered an endogenous market structure where foreign firms benefit from a better technology than domestic firms

\footnotetext{
${ }^{1}$ Cheng et al. (2018) cite several works that confirm that management and innovation compensation effects could offset compliance costs.
} 
(Dijkstra et al., 2011) or from a first-mover advantage (Elliott \& Zhou, 2013) leading to a situation in which a more stringent policy confers advantage to foreign firms. All in all, whether the pollution haven effect or the pollution halo effect dominates remains an empirical question with discrepant answers.

Another important flaw of the PHH is the one related with other important determinants of FDI that, if omitted could lead to a spurious relationship between FDI and environmental stringency. One noticeable determinant of FDI highlighted by economic geographic model is market size for horizontal FDI and transport costs for re-exporting FDI. In this line, Sanna-Randaccio and Sestini (2012) extend Markusen et al. (1993)'s model to take into account changes in environmental policy. The authors conclude that firms would relocate only if the regulation's gap is large enough to offset re-exporting costs to the market of origin. Tang (2015) predicts that export-orientated FDI is more sensitive to stricter environmental regulations than local-market orientated FDI. For the case of European firms, Candau and Dienesch (2017) show that a better access to a large market of origin from the host country may outset the cost of tougher environmental regulation for export platform FDI.

The literature also emphasised the role of institutions in attracting FDI. In particular, corruption can be a mechanism that promotes lax environmental standards (Fredriksson et al., 2003 and Javorcik \& Wei, 2003). ${ }^{2}$ Then, these authors suggest that not accounting for the link between institutional quality and environmental regulation could explain why previous literature failed to find empirical support for the pollution haven hypothesis. Candau and Dienesch (2017) present a theoretical model and empirical evidence for the case of European MNEs investment decisions that supports the pollution haven hypothesis for those countries which have intermediates levels of corruption, while it does not apply for those countries with the lowest or highest levels of corruption. Similarly, but more generally, Contractor et al. (2020) demonstrate that MNEs take into account different aspects of regulations and governance all together when choosing where to invest. MNEs are willing to trade-off less efficient entry and exit regulations in exchange for stronger contract enforcement. Following this approach, this study investigates whether MNEs are willing to accept stricter environmental regulation in exchange of better environment for business.

Another concern in order to accurately assess the impact of environmental regulations on FDI is the possibility of a reverse causality that might arise if governments relax the stringency in order to attract pollutant firms, or if the increase in FDI gives foreign investors sufficient power to negotiate pollution levies with local authorities. Instead, some authors found contrary evidence. Cheng et al. (2018) emphasise that FDI inflows have increased both the number and severity of local environmental regulations. Brucal et al. (2019) conclude that FDI increases the overall energy usage due to expansion of output while it decreases the plant's

${ }^{2}$ Likewise, Rivera and Oh (2013) and Javorcik and Wei, (2003) also show that democratic level moderates the relationship between environmental stringency and FDI. 
energy intensity. All in all, such effects (pressures to lessen the measures or increase stringency in response to growing FDI) are exerted once the MNE is operating in the country, what would reduce the case for a two-way causality in location's choice models.

Almost all the previously mentioned studies focus on FDI, regardless the entry mode. To the best of the authors' knowledge, there are only two exceptions. LeonGonzalez and Tole (2015) that study M\&As in the mining industry, at the world level between 1994 and 2006 and find no evidence of pollution havens in this industry. If anything, buyers from countries with high levels of environmental stringency are more likely to invest and make larger investments in countries with similar requirements' level. Bialek and Weichenrieder (2015) gain robust support for PHH for greenfields investments from Germany in polluting industries. In turn, M\&A investments in low polluting industries seem to be attracted by stricter environmental regulation, this could be explained by competitiveness effects associated with grandfathering ${ }^{3}$ as well as the "green image" that German firms are trying to keep. Even if the specific contexts of their analysis do not allow to generalise their results, these two studies tend to refute the $\mathrm{PHH}$ hypothesis for M\&As.

\section{Empirical strategy and data}

We employ an augmented gravity equation to determine the influence of countries' environmental policy on cross-border M\&As' location choices. The gravity model has been previously successful in explaining bilateral FDI flows, and is theoretically founded for the specific case of M\&As (Head \& Ries, 2008). Accordingly, using a Poisson Pseudo-Maximum Likelihood estimator, ${ }^{4}$ we estimate the following equation:

$$
M A_{i j t}=e^{\left(\alpha+X_{i j t}+D_{i j}+Z_{i t}+Z_{j t}+\lambda_{i}+\lambda_{j}+\lambda_{t}\right)}+e_{i j t}
$$

where $M A_{i j t}$ is the number of M\&As projects from country $i$ (source) to country $j$ (host) in year $t$. In this way, the model focuses on the extensive margin: the determinants of new bilateral relationships and of MNEs' M\&As location decisions. M\&As data are retrieved from Eikon Thomson Reuters, and covers the period 19952015. The Environmental Policy Stringency Index (EPS Index) is provided for 28 OECD countries and 6 non-OECD countries, a smaller sample of countries than data

${ }^{3}$ They argue that greenfield projects usually need to obey all the latest environmental requirements whereas M\&As involve local firms that usually, due to grandfathering policies, remain unaffected by the latest rules and need to adhere to the older regulations only. Moreover, in the case of an M\&A project, the acquisition price may already be a function of the regulation faced by the company as the purchaser of the existing plant is only willing to pay the present discounted value of future profits.

4 The Poisson Pseudo-Maximum Likelihood estimator overcomes the heteroskedasticity issues from OLS's estimates and include in the analysis the zeros usually present in bilateral FDI databases (Santos-Silva \& Tenreyro, 2006). 
concerning M\&As. Accordingly, we focus on two samples depending on whether we consider only the environmental policy of the host (sample 1 with 100 source and 34 host countries) or the environmental policies in both the source and host countries (sample 2 with 34 source and host countries). The list of countries included in the samples is available in the appendix. Summary statistics of the variables presented in the following lines, together with the sources, are reported in Table 1.

The model includes home, host and year fixed effects to control, respectively, for the home and host countries' characteristics (i.e. multilateral resistance) and macroeconomic trends (e.g. Anderson \& Van Wincoop, 2003; Head \& Ries, 2008; Paniagua \& Sapena, 2014). Moreover, to test the robustness of our results, to overcome possible omitted variable bias and to address the endogeneity issues between FDI and bilateral agreements (Baier \& Bergstrand, 2009; Bergstrand \& Egger, 2013), we replace the $D_{i j}$ set of variables, and $\lambda_{i}$ and $\lambda_{j}$ fixed effects with country pair fixed effects.

$X_{i j t}$ and $D_{i j}$ are respectively set of bilateral time-variant and time-invariant bilateral determinants of FDI usually present in the literature. Among $X_{i j t}$, we include the logarithm of the product of gross domestic product between home and host country (GDP sum), the difference between home and host country's logarithm of GDP per capita, exchange rates, trade agreements and investment agreements. The number of bilateral M\&As is expected to be positively moderated by the combined economic size of the home and host country (Paniagua \& Sapena, 2014), and M\&As are expected to go from more capital intensive countries, or wealthier countries, to less intensive ones (Carril-Caccia \& Pavlova, 2020), being this particularly true for firms seeking to benefit from labour abundant countries.

Depreciation of the exchange rate is likely to foster the number of inward M\&As, by pushing down the acquisition price of domestic firms. However, significant currency depreciation can have negative implications on MNEs' profits, and thus restrain them from investing in countries whose currencies are becoming systematically weaker. Following di Giovanni (2005), the bilateral exchange rate measure is the log difference of period $t$ and $t-1$ of the ratio between $i$ and $j$ nominal exchange rate against US dollar: ${ }^{5}$

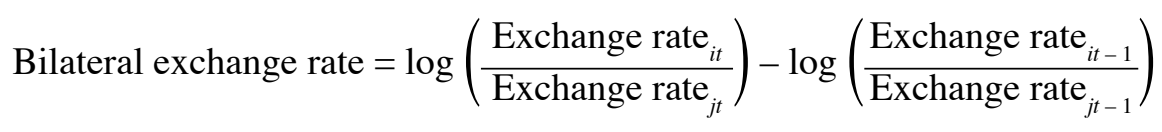

Bilateral investment treaties are expected to promote bilateral FDI between signing parties and to reduce expropriation risks (e.g. Bergstrand \& Egger, 2013). In turn, the role of trade agreements is ambiguous. On the one hand, signing a bilateral trade agreement can incentivize vertical, export platform and export supporting

\footnotetext{
${ }^{5}$ Ideally, we would like to calculate bilateral real exchange rates. But, the limited availability of consumer price indexes combined with the limited available information regarding environmental regulation significantly reduce our sample of analysis.
} 
TABLE 1

DESCRIPTIVE STATISTICS

\begin{tabular}{|c|c|c|c|c|c|c|}
\hline Variable & Obs. & Mean & Std. Dev. & Min & Max & Source \\
\hline M\&As projects & 30,343 & 2.94 & 13.22 & 0 & 379 & $\begin{array}{l}\text { Eikon Thomson } \\
\text { Reuters }\end{array}$ \\
\hline GDPsum (log) & 30,343 & 53.33 & 2.23 & 45.40 & 60.56 & \multirow{2}{*}{$\begin{array}{l}\text { World Bank } \\
\text { Development } \\
\text { Indicators }\end{array}$} \\
\hline Difference in GDPpc & 30,343 & -0.14 & 1.63 & -4.88 & 4.95 & \\
\hline Bilateral exchange rate & 30,343 & 0.01 & 0.68 & -9.37 & 13.46 & $\begin{array}{l}\text { International Monetary } \\
\text { Fund's International } \\
\text { Financial Statistics }\end{array}$ \\
\hline Distance $(\log )$ & 30,321 & 8.31 & 1.01 & 5.08 & 9.86 & \multirow{7}{*}{$\begin{array}{l}\text { CEPII } \\
\text { (Head et al., 2010) }\end{array}$} \\
\hline Contiguity & 30,343 & 0.06 & 0.23 & 0 & 1 & \\
\hline Language & 30,343 & 0.12 & 0.32 & 0 & 1 & \\
\hline Legal system & 30,321 & 0.30 & 0.46 & 0 & 1 & \\
\hline Colony & 30,343 & 0.05 & 0.23 & 0 & 1 & \\
\hline Previously same country & 30,343 & 0.01 & 0.12 & 0 & 1 & \\
\hline Religion & 30,321 & 0.19 & 0.25 & 0 & 0.98 & \\
\hline Migration & 30,343 & 6.77 & 3.54 & 0 & 15.27 & $\begin{array}{l}\text { United Nations' } \\
\text { Population Division } \\
\text { (United Nations, } \\
\text { Department of } \\
\text { Economic and Social } \\
\text { Affairs, Population } \\
\text { Division, 2017) }\end{array}$ \\
\hline Trade agreement & 30,343 & 0.34 & 0.47 & 0 & 1 & $\begin{array}{l}\text { World Trade } \\
\text { Organization (Hofmann } \\
\text { et al., 2017) }\end{array}$ \\
\hline Investment agreement & 30,343 & 0.21 & 0.40 & 0 & 1 & $\begin{array}{l}\text { UNCTAD's } \\
\text { International } \\
\text { Investment Agreements } \\
\text { Navigator (UNCTAD, } \\
\text { 2020) }\end{array}$ \\
\hline $\begin{array}{l}\text { Lack of corruption } \\
\text { (home) }\end{array}$ & 30,343 & 0.90 & 1.00 & -1.43 & 2.47 & \multirow{2}{*}{$\begin{array}{l}\text { World Bank's } \\
\text { Worldwide Governance } \\
\text { Indicators }\end{array}$} \\
\hline $\begin{array}{l}\text { Lack of corruption } \\
\text { (host) }\end{array}$ & 30,343 & 1.03 & 0.99 & -1.17 & 2.47 & \\
\hline $\begin{array}{l}\text { Environmental Policy } \\
\text { Stringency Index } \\
\text { (home) }\end{array}$ & 16,809 & 1.79 & 0.97 & 0.38 & 4.13 & \multirow{2}{*}{$\begin{array}{l}\text { OECD (Bota and } \\
\text { Kozluk, 2014) }\end{array}$} \\
\hline $\begin{array}{l}\text { Environmental Policy } \\
\text { Stringency Index (host) }\end{array}$ & 30,343 & 1.79 & 0.99 & 0.38 & 4.13 & \\
\hline
\end{tabular}

NOTE: Environmental Policy Stringency Index (home) descriptive statistics is limited to only the country sample in which are 34 home and host countries, while the remaining variables' descriptive statistics are based on 100 home countries and 34 host countries.

SOURCE: Authors' own calculations. 
FDI (e.g. Ekholm et al., 2007; Hanson et al., 2005; Krautheim, 2013). Accordingly, FDI is positively related to the formation of global value chains (Carril-Caccia \& Pavlova, 2020; Contractor et al., 2020; Martinez-Galan \& Fontoura, 2019). On the other hand, in the context of horizontal FDI type, bilateral trade liberalization is expected to have a negative impact on FDI, since trade and FDI substitute each other as alternative strategies to serve a foreign market (e.g. Antras \& Yeaple, 2014; Jang, 2011; Horstmann \& Markusen, 1987).

$D_{i j}$ is a set of variables representing the transaction costs that MNEs might face when investing abroad. $D_{i j}$ includes the logarithm of geographic distance, a religious affinity index, the logarithm of country $i$ 's migration stock in country $j$ in 1990, and a set of dummies which take value one whenever a pair of countries share border, language, legal system and colonial past, or have been the same country in the past. Sharing a religion, colonial past, legal system and language is expected to foster bilateral M\&As between countries, while geographic distance is expected to moderate negatively M\&As. Moreover, the MNEs' home country population living abroad can affect its investment decisions. Migrants can help MNEs by providing valuable information about their homeland, and by reducing transaction costs derived from cultural and institutional differences (e.g. Cuadros et al., 2016; Javorcik et al., 2011). The bilateral migration stock is evaluated in the year 1990 to limit the potential endogeneity between this variable and M\&As.

$Z_{i t}$ and $Z_{j t}$ respectively represent home and host country time-varying characteristics. In this set of variables, we include an indicator of lack of corruption and the Environmental Stringency Index. World Bank's lack of corruption index (Kaufmann et al., 2011) is a widely used indicator to account for countries' institutional quality (e.g. Candau \& Dienesch, 2017). This index ranges from -2.5 to +2.5 , from low to high lack of corruption. Since cross-border M\&As are often used by firms to achieve convergence in cross-border corporate governance (Erel et al., 2012; Rossi \& Volpin, 2004), we expect the lack of corruption in the home country to favour outward M\&As. Furthermore, high institutional quality is expected to foster the development of MNEs and their outward investment (Chen \& Shapiro, 2015; Wang et al., 2014). Turning to the environment of the host country, higher institutional quality may favour inward FDI as long as it reduces the costs of doing business (Wei, 2000). Nevertheless, MNEs whose investment is driven by accessing low labour costs or natural resources might be more attracted towards countries with low institutional quality (e.g. Adam \& Filippaios, 2007; Egger \& Winner, 2005). Then, the role of host countries' institutional quality is ambiguous. Our variables of interest are the level of Environmental Policy Stringency Index in the home and host country. This index is constructed by Botta and Koźluk (2014), and retrieved from the OECD. ${ }^{6}$ The index ranges between 0-6, from "not stringent" to "highest degree of stringency". Thus, a negative and significant coefficient for the EPS in the

${ }^{6}$ Botta and Koźluk (2014) construct an index for the energy sector and for the broader economy. In the present paper we only use the second. 
host country would confirm that laxer environmental regulation attracts M\&As. As regards the EPS in the source country, a positive and significant coefficient would confirm the other side of the $\mathrm{PHH}$, that is, the deterrent effect of more stringent environmental policy on cross-border M\&As.

We use the EPS Index from Botta and Koźluk (2014) because it allows us to cover a long period of analysis (1995-2015). This index has been widely used by the previous literature. ${ }^{7}$ For testing the PHH, EPS is considered as a more appropriate indicator than $\mathrm{CO}_{2}$ or $\mathrm{SO}_{2}$ emissions (used, for example, in Kahouli \& Omri, 2017, and Xing \& Kolstad, 2002). Since the level of greenhouse gases emission is determined by economic activity, and thus is prone to be endogenous to FDI. In addition, if a positive relationship between FDI and countries' emissions were found, it wouldn't be clear whether this positive link is due to M\&As being directed toward those countries which have laxer environmental regulation, or if its driven by MNEs seeking to benefit from agglomeration economies (Wagner \& Timmins, 2009). Alternatively, some studies use pollution abatement costs; this is a more precise measure but unfortunately with a limited country and period coverage (see Cole et al., 2017). An even more precise measure consists in studying the impact of a specific change in environmental regulations (Hanna, 2010; Nuñez-Rocha \& Martínez-Zarzoso, 2019) but these natural experiments are scarce, and would considerably limit the group of countries and period subject of study.

In addition, environmental regulation is less prone to be endogenous if we consider bilateral M\&As instead of aggregate M\&A. Indeed, it is little likely that M\&As projects from a specific country influence the environmental regulation of the host before investing. ${ }^{8}$ In comparison with other measure, the main limitation of the EPS Index proposed by Botta and Koźluk (2014) is that it only covers 34 countries. ${ }^{9}$ Nevertheless, this is not a significant restriction for our analysis, since these 34 economies are the source and host of $90 \%$ of global cross-border M\&As projects during the period 1995-2015. Moreover, as illustrated in Figure 3, our sample covers countries whose levels of pollution are relatively high in comparison with those which are not included in the analysis. Finally, this group of countries represents $81 \%$ of the global $\mathrm{CO}_{2}$ emissions. ${ }^{10}$

${ }^{7}$ The Botta and Koźluk (2014) EPS Index has been used for addressing multiple subjects like politics (Mavisakalyan \& Tarverdi, 2019), air pollution (Martínez-Zarzoso \& Oueslati, 2018), FDI determinants (Garsous \& Kozluk, 2017) or productivity growth (Wang et al., 2019)

${ }^{8}$ However, environmental policy is not fully exogenous to FDI (e.g. Dam \& Scholtens, 2008). We account for this in the robustness analysis.

${ }^{9}$ For instance, the World Economic Forum survey on perceived environmental stringency by managers covers more than 140 countries, but it would limit our period of analysis to years 2008, 2009, 2011, 2013 and 2015.

${ }^{10}$ Calculations based on the $\mathrm{CO}_{2}$ emissions data from World Bank's Development indicator in year 2015 for 204 countries. 


\section{FIGURE 3}

\section{DENSITY OF COUNTRIES BY LEVEL CO 2 EMISSIONS PER CAPITA IN 2015}

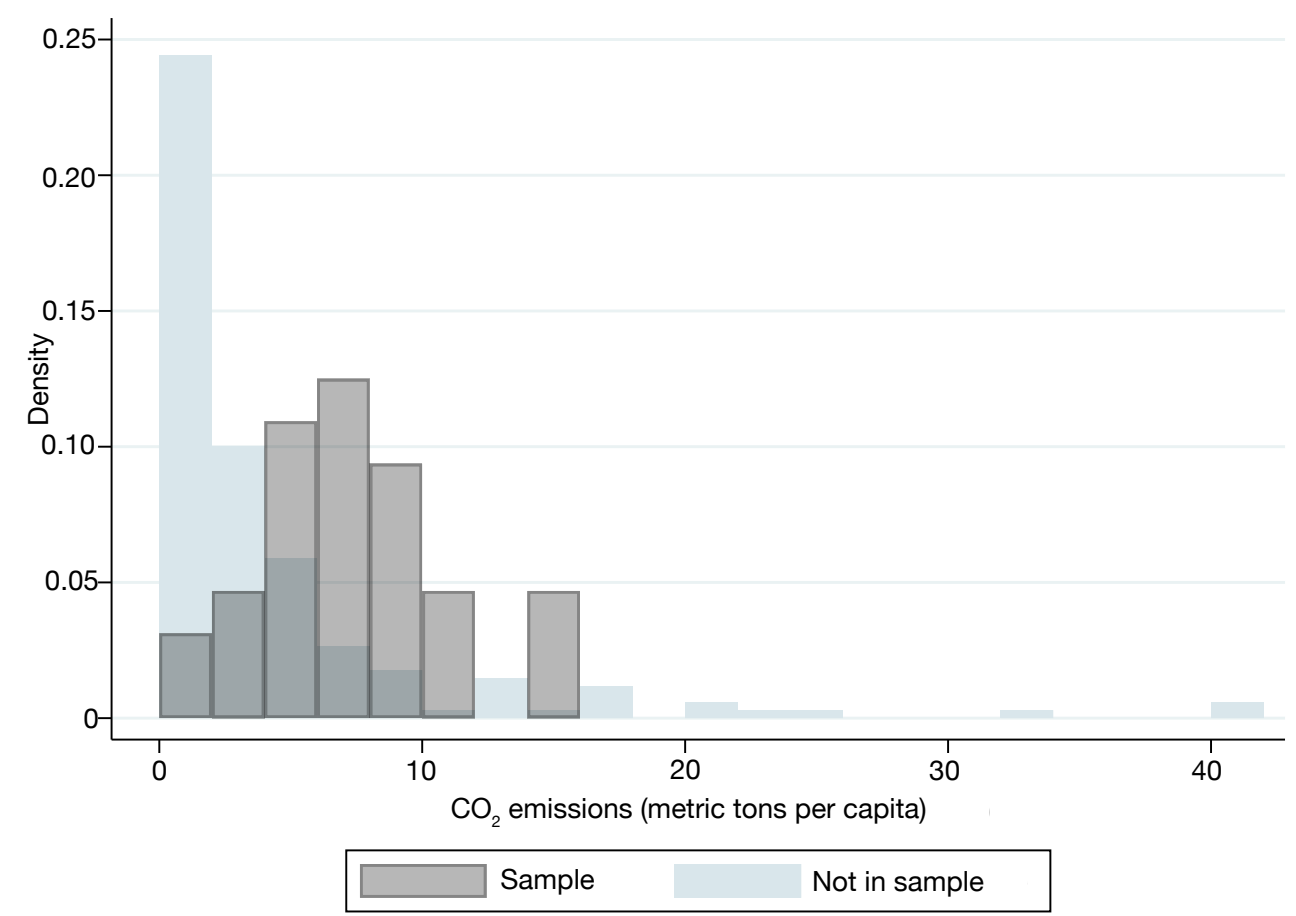

NOTE: Data for 202 countries in the year 2015. Retrieved from World Bank's Development Indicators. SOURCE: Authors' own elaboration.

\section{Results}

\subsection{The impact of EPS on cross-border M\&As}

Results from our empirical analysis are presented in Table 2. Equation [1] is estimated for two different samples: sample 1 with 100 home and 34 host countries (columns 1 to 4), and sample 2 with 34 home and host countries (columns 5 to 8). The coefficients of the usual determinants of FDI have the expected sign and significance. M\&As projects are positively correlated with the home and host countries' combined economic size (GDPsum) and proximity measured by sharing a language, legal system, religion or history (Previously same country and colony). Moreover, M\&As from country $i$ to country $j$ are fostered by migrants from country $i$ living in country $j$. In accordance, geographic distance has a negative effect on bilateral M\&As. The bilateral exchange rate has no significant effect on M\&A reflecting its ambiguous predicted effect. Indeed, the extent to which $M \& A s$ are attracted by the depreciation of the host country currency is likely to be offset by the negative implications of the depreciation on MNEs' profits. Finally, when country-pair fixed effects are included, and thus the endogeneity issue between FDI and bilateral agreements is accounted for, bilateral investment agreements exert a positive and significant effect, while trade agreements fail to be significant. 


\section{TABLE 2}

THE IMPACT OF EPS ON CROSS-BORDER M\&AS

\begin{tabular}{|c|c|c|c|c|c|c|c|c|}
\hline & (1) & (2) & (3) & (4) & (5) & (6) & (7) & (8) \\
\hline & \multicolumn{4}{|c|}{ Sample 1} & \multicolumn{4}{|c|}{ Sample 2} \\
\hline GDPsum & $\begin{array}{c}0.660 * * * \\
(0.086)\end{array}$ & $\begin{array}{c}0.650 * * * \\
(0.083)\end{array}$ & $\begin{array}{c}0.642^{* * * *} \\
(0.078)\end{array}$ & $\begin{array}{c}0.633 * * * \\
(0.074)\end{array}$ & $\begin{array}{c}0.543 * * * \\
(0.062)\end{array}$ & $\begin{array}{c}0.539 * * * \\
(0.061)\end{array}$ & $\begin{array}{c}0.553 * * * \\
(0.061)\end{array}$ & $\begin{array}{c}0.548 * * * \\
(0.060)\end{array}$ \\
\hline Difference in GDPpc & $\begin{array}{c}0.033 \\
(0.082)\end{array}$ & $\begin{array}{c}0.040 \\
(0.078)\end{array}$ & $\begin{array}{c}0.041 \\
(0.079)\end{array}$ & $\begin{array}{c}0.048 \\
(0.075)\end{array}$ & $\begin{array}{c}0.116 * * \\
(0.056)\end{array}$ & $\begin{array}{c}0.122 * * \\
(0.056)\end{array}$ & $\begin{array}{l}0.096^{*} \\
(0.057)\end{array}$ & $\begin{array}{l}0.102 * \\
(0.057)\end{array}$ \\
\hline Exchange rate & $\begin{array}{c}-0.004 \\
(0.009)\end{array}$ & $\begin{array}{l}-0.003 \\
(0.009)\end{array}$ & $\begin{array}{l}-0.006 \\
(0.009)\end{array}$ & $\begin{array}{l}-0.006 \\
(0.009)\end{array}$ & $\begin{array}{l}-0.006 \\
(0.009)\end{array}$ & $\begin{array}{l}-0.006 \\
(0.009)\end{array}$ & $\begin{array}{l}-0.008 \\
(0.009)\end{array}$ & $\begin{array}{l}-0.008 \\
(0.009)\end{array}$ \\
\hline Distance $(\log )$ & $\begin{array}{c}-0.617 * * * \\
(0.057)\end{array}$ & $\begin{array}{c}-0.616^{* * *} * \\
(0.057)\end{array}$ & & & $\begin{array}{c}-0.557 * * * \\
(0.048)\end{array}$ & $\begin{array}{c}-0.556^{* * * *} \\
(0.048)\end{array}$ & & \\
\hline Contiguity & $\begin{array}{c}0.072 \\
(0.086)\end{array}$ & $\begin{array}{c}0.072 \\
(0.086)\end{array}$ & & & $\begin{array}{c}0.128 \\
(0.082)\end{array}$ & $\begin{array}{c}0.129 \\
(0.082)\end{array}$ & & \\
\hline Language & $\begin{array}{c}0.367 * * * \\
(0.122)\end{array}$ & $\begin{array}{c}0.366^{* * * *} \\
(0.122)\end{array}$ & & & $\begin{array}{l}0.172 * \\
(0.089)\end{array}$ & $\begin{array}{l}0.173^{*} \\
(0.089)\end{array}$ & & \\
\hline Legal system & $\begin{array}{c}0.222 * * * \\
(0.083)\end{array}$ & $\begin{array}{c}0.222 * * * \\
(0.083)\end{array}$ & & & $\begin{array}{c}0.455^{* * * *} \\
(0.050)\end{array}$ & $\begin{array}{c}0.455^{* * * *} \\
(0.050)\end{array}$ & & \\
\hline Colony & $\begin{array}{c}0.319 * * * \\
(0.092)\end{array}$ & $\begin{array}{c}0.319 * * * \\
(0.091)\end{array}$ & & & $\begin{array}{c}0.246^{* * * *} \\
(0.081)\end{array}$ & $\begin{array}{c}0.246^{* * * *} \\
(0.081)\end{array}$ & & \\
\hline Previously same country & $\begin{array}{c}0.627 * * \\
(0.318)\end{array}$ & $\begin{array}{c}0.628 * * \\
(0.317)\end{array}$ & & & $\begin{array}{c}0.065 \\
(0.128)\end{array}$ & $\begin{array}{c}0.065 \\
(0.128)\end{array}$ & & \\
\hline Religion & $\begin{array}{c}1.309 * * * \\
(0.207)\end{array}$ & $\begin{array}{c}1.309 * * * \\
(0.207)\end{array}$ & & & $\begin{array}{c}0.867 * * * \\
(0.144)\end{array}$ & $\begin{array}{c}0.868 * * * \\
(0.144)\end{array}$ & & \\
\hline Migration & $\begin{array}{c}0.077 * * * \\
(0.017)\end{array}$ & $\begin{array}{c}0.077 * * * \\
(0.017)\end{array}$ & & & $\begin{array}{c}0.088 * * * \\
(0.018)\end{array}$ & $\begin{array}{c}0.088 * * * \\
(0.018)\end{array}$ & & \\
\hline Trade agreement & $\begin{array}{c}0.108 \\
(0.096)\end{array}$ & $\begin{array}{c}0.110 \\
(0.095)\end{array}$ & $\begin{array}{l}-0.045 \\
(0.080)\end{array}$ & $\begin{array}{l}-0.040 \\
(0.078)\end{array}$ & $\begin{array}{c}0.033 \\
(0.072)\end{array}$ & $\begin{array}{c}0.033 \\
(0.072)\end{array}$ & $\begin{array}{l}-0.039 \\
(0.089)\end{array}$ & $\begin{array}{l}-0.036 \\
(0.090)\end{array}$ \\
\hline Investment agreement & $\begin{array}{l}-0.110 \\
(0.108)\end{array}$ & $\begin{array}{l}-0.110 \\
(0.108)\end{array}$ & $\begin{array}{c}0.321 * * * \\
(0.099)\end{array}$ & $\begin{array}{c}0.312 * * * \\
(0.100)\end{array}$ & $\begin{array}{c}0.084 \\
(0.086)\end{array}$ & $\begin{array}{c}0.083 \\
(0.086)\end{array}$ & $\begin{array}{c}0.401 * * * \\
(0.108)\end{array}$ & $\begin{array}{c}0.390 * * * \\
(0.108)\end{array}$ \\
\hline Lack of corruption (home) & $\begin{array}{c}0.458 * * * \\
(0.084)\end{array}$ & $\begin{array}{c}0.455^{* * *} * \\
(0.084)\end{array}$ & $\begin{array}{c}0.379 * * * \\
(0.080)\end{array}$ & $\begin{array}{c}0.374 * * * \\
(0.081)\end{array}$ & $\begin{array}{c}0.306 * * * \\
(0.096)\end{array}$ & $\begin{array}{c}0.303 * * * \\
(0.095)\end{array}$ & $\begin{array}{c}0.282 * * * \\
(0.099)\end{array}$ & $\begin{array}{c}0.279 * * * \\
(0.098)\end{array}$ \\
\hline Lack of corruption (host) & $\begin{array}{c}0.046 \\
(0.084)\end{array}$ & $\begin{array}{c}0.050 \\
(0.081)\end{array}$ & $\begin{array}{c}0.043 \\
(0.080)\end{array}$ & $\begin{array}{c}0.047 \\
(0.078)\end{array}$ & $\begin{array}{c}0.080 \\
(0.073)\end{array}$ & $\begin{array}{c}0.078 \\
(0.072)\end{array}$ & $\begin{array}{c}0.075 \\
(0.072)\end{array}$ & $\begin{array}{c}0.073 \\
(0.070)\end{array}$ \\
\hline EPS (home) & & & & & & $\begin{array}{c}-0.041 * * \\
(0.020)\end{array}$ & & $\begin{array}{c}-0.040 * * \\
(0.020)\end{array}$ \\
\hline EPS (host) & & $\begin{array}{l}-0.053 \\
(0.032)\end{array}$ & & $\begin{array}{l}-0.050 \\
(0.031)\end{array}$ & & $\begin{array}{l}-0.021 \\
(0.025)\end{array}$ & & $\begin{array}{l}-0.023 \\
(0.025)\end{array}$ \\
\hline Observations & 30,321 & 30,321 & 30,343 & 30,343 & 16,717 & 16,717 & 16,717 & 16,717 \\
\hline Country FE & $\mathrm{X}$ & $\mathrm{X}$ & & & $\mathrm{X}$ & $\mathrm{X}$ & & \\
\hline Country pair FE & & & $\mathrm{X}$ & $\mathrm{X}$ & & & $X$ & $\mathrm{X}$ \\
\hline Year FE & $\mathrm{X}$ & $\mathrm{X}$ & $\mathrm{X}$ & $\mathrm{X}$ & $\mathrm{X}$ & $\mathrm{X}$ & $\mathrm{X}$ & $\mathrm{X}$ \\
\hline Pseudo R2 & 0.777 & 0.777 & 0.825 & 0.826 & 0.803 & 0.803 & 0.832 & 0.832 \\
\hline
\end{tabular}

NOTE: PPML estimator. Robust standard error in parenthesis. ${ }^{*} p<0.10, * * p<0.05, * * * p<0.01$. 
Turning to the influence of the quality of institutions on inward M\&As, there is a vast literature that emphasises the lack of corruption as an important driver of inbound FDI, except for some resource seeking investments. Our results confirm the ambiguous effect since Lack of corruption in the host country is not significant in any models. In contrast, high institutional quality is expected to favour outward M\&As, hypothesis which is confirmed by a positive and significant sign.

Our coefficient of interest is the one associated with the EPS Index in the home and host countries. When a wider sample of (home) countries investing abroad is analysed (sample 1 in columns 2 and 4), results point out a negative, but not significant, relationship between the capacity of attracting M\&As and the degree of EPS in the host. This result is confirmed by estimates that cover the small group of countries (sample 2 in columns 6 and 8). Interestingly, estimates in sample 2 report that home countries' EPS has a negative impact on outward cross-border M\&As (columns 6 and 8). This result is at odd with the PHH, since a stricter environmental policy is expected to increase the willingness of MNEs to invest abroad. At first sight, this result would contradict the first part of the PHH since a more stringent environmental regulation would reduce the incentives for outward M\&As. Nonetheless, since institutions can influence how environmental regulations affect inward and outward M\&A, we deep in the analysis of this interaction effect in the next section.

\subsection{Trade-off between EPS and institutional quality}

In the previous section, we do not find evidence supporting the PHH. Nevertheless, countries' institutional quality may moderate the effect of countries' EPS on their capacity of attracting cross-border M\&As. Indeed, MNEs may face a trade-off between countries environmental regulation stringency and institutional quality.

Figure 4 illustrates the link between lack of corruption on the one hand and countries' EPS on the other hand. As expected, the graph illustrates a positive relationship between institutional quality and EPS's level consistent with the hypothesis that corruption could be a mechanism that promotes lax environmental standards. Since our restricted sample of analysis is formed mostly by OECD countries, most countries in our sample present a relatively high level of institutional quality. ${ }^{11}$ However, the figure also highlights a significant heterogeneity in countries' lack of corruption, at equal EPS levels.

In order to assess whether countries' level of lack corruption negatively or positively moderates the impact of EPS on cross-border M\&As, we modify equation [1] by adding the interaction of the EPS Index with the institutional index. To conserve on space, Table 3 only reports the estimates that include country pair fixed effects since estimates reported in Table 2 do not significantly vary, whether we include or

${ }^{11}$ For the period 1995-2015, the global average for lack of corruption indexes is equal to 0 . The average EPS for the 34 countries of the sample is 1.79 . 
FIGURE 4

CORRUPTION AND EPS

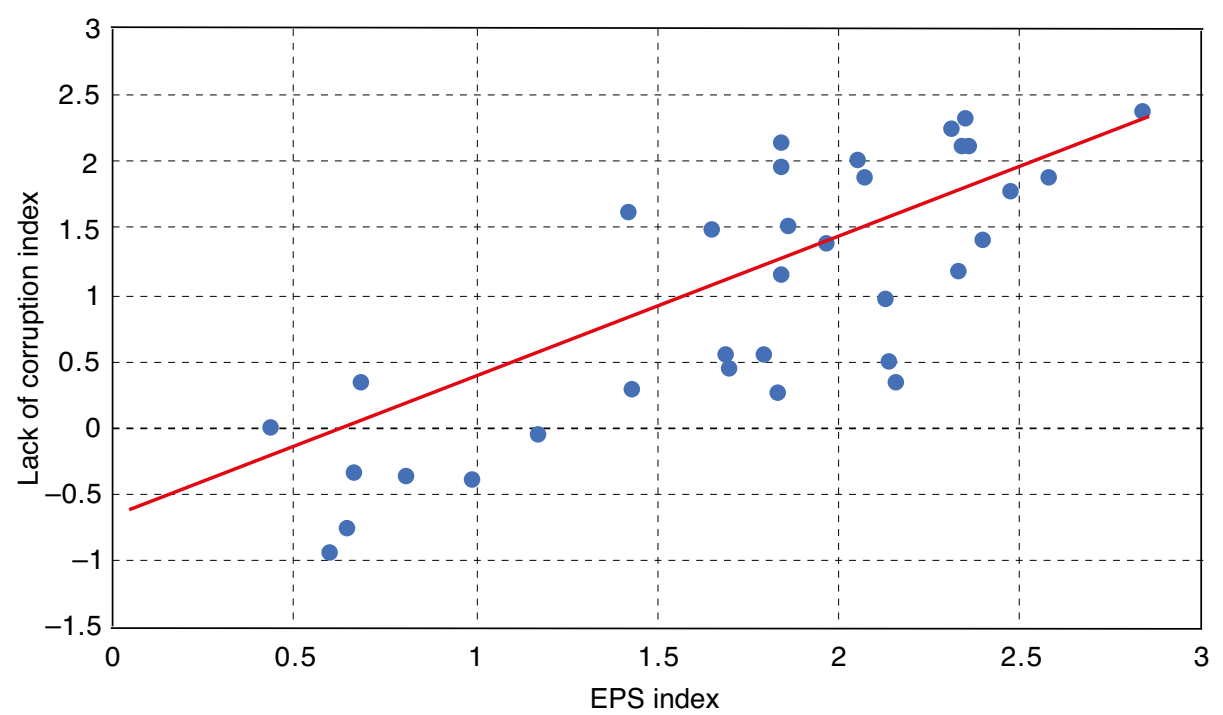

NOTE: Average values for the period 1995-2015.

SOURCE: Authors' own elaboration.

not country pair fixed effects. Results support the hypothesis posited by Fredriksson et al. (2003) and other authors, and thus corroborate that the impact of EPS on host countries' capacity of attracting M\&As is linked to the institutional context. For both samples, estimates show that increasing the stringency of environmental regulation would sizeably reduce the attractiveness of the country in terms of M\&As. Increasing the EPS Index in one point could reduce the number of inward M\&As by $13.5 \%-15.6 \%$. However, this negative link between M\&As and EPS could be compensated by improvement in institutional quality. By reducing corruption, countries could counteract the deterrent effect of a stringent environmental policy. Accordingly, the $\mathrm{PHH}$ is especially relevant for countries with low institutional quality. Figure 5 illustrates this relationship for different levels of both indexes. For country with bad institutional quality, increasing the stringency of environmental regulation would significantly decrease the number of inward M\&As' projects. Interestingly, in countries with excellent quality of institutions, more stringent regulations would not discourage M\&As. Then, the PHH would not apply for countries with extremely good institutions while countries with very bad institutions have more incentive to adopt lenient environmental regulation. According to Figure 4 , there are considerable room for improvements in terms of reducing corruption in the countries of our reduced sample: half of the countries do not reach a lack of corruption level of 1 and their EPS is above 1. For these intermediate countries, more 
stringent environmental regulations could reduce considerably their attractiveness if they are not compensated by a reduction of corruption.

Concerning the context that would push firms to invest abroad, estimations presented in Table 3 shed new light on the first part of the PHH. Results of the previous section (Table 2) evidence a negative effect of EPS at home on outward FDI. However, once we include the interaction effect between EPS at home and corruption, the coefficient of EPS at home turns to be positive and barely significant while the interaction is negative and highly significant. The first result would

\section{TABLE 3}

EPS AND INSTITUTIONAL QUALITY

\begin{tabular}{|c|c|c|}
\hline & $\begin{array}{c}(1) \\
\text { Sample } 1 \\
\end{array}$ & $\begin{array}{c}(2) \\
\text { Sample } 2 \\
\end{array}$ \\
\hline GDPsum & $\begin{array}{c}0.646^{* * * *} \\
(0.075)\end{array}$ & $\begin{array}{l}0.512^{* * * *} \\
(0.061)\end{array}$ \\
\hline Difference in GDPpc & $\begin{array}{c}0.037 \\
(0.076)\end{array}$ & $\begin{array}{l}0.146^{* *} \\
(0.059)\end{array}$ \\
\hline Bilateral exchange rate & $\begin{array}{l}-0.008 \\
(0.009)\end{array}$ & $\begin{array}{l}-0.010 \\
(0.009)\end{array}$ \\
\hline Trade agreement & $\begin{array}{l}-0.013 \\
(0.073)\end{array}$ & $\begin{array}{c}0.002 \\
(0.090)\end{array}$ \\
\hline Investment agreement & $\begin{array}{l}0.339^{* * * *} \\
(0.102)\end{array}$ & $\begin{array}{l}0.394^{* * * *} \\
(0.111)\end{array}$ \\
\hline Lack of corruption (home) & $\begin{array}{l}0.378^{* * *} \\
(0.080)\end{array}$ & $\begin{array}{l}0.283^{* * * *} \\
(0.098)\end{array}$ \\
\hline Lack of corruption (host) & $\begin{array}{l}-0.041 \\
(0.094)\end{array}$ & $\begin{array}{c}0.081 \\
(0.096)\end{array}$ \\
\hline Environmental Policy Stringency Index (home) & & $\begin{array}{c}0.069^{*} \\
(0.037)\end{array}$ \\
\hline$\times$ Lack of corruption (home) & & $\begin{array}{c}-0.078^{* * *} \\
(0.021)\end{array}$ \\
\hline Environmental Policy Stringency Index (host) & $\begin{array}{c}-0.135^{* *} \\
(0.053)\end{array}$ & $\begin{array}{c}-0.156^{* * * *} \\
(0.049)\end{array}$ \\
\hline$\times$ Lack of corruption (host) & $\begin{array}{l}0.049^{* * *} \\
(0.020)\end{array}$ & $\begin{array}{l}0.101^{\text {**** }} \\
(0.025)\end{array}$ \\
\hline $\begin{array}{l}\text { Observations } \\
\text { Country FE } \\
\text { Country pair FE } \\
\text { Year FE } \\
\text { Pseudo R2 }\end{array}$ & $\begin{array}{c}30,343 \\
\\
X \\
X \\
0.826\end{array}$ & $\begin{array}{c}16,717 \\
X \\
X \\
0.833\end{array}$ \\
\hline
\end{tabular}

NOTE: PPML estimator. Robust standard error in parenthesis. $* p<0.10, * * p<0.05, * * * p<0.01$. 
be weakly aligned with the first side of the PHH. Nonetheless, this positive link between outward M\&As and EPS is negatively moderated by home countries' institutional quality. As a country reduces corruption, MNEs have less incentives to invest abroad when their home country turns to more stringent environmental laws. Figure 6 illustrates the joint effects of both indicators on outward M\&As. Indeed, above a certain level, more stringent environmental measures would have no effect on outward M\&As (Lack of corruption above 2), or would even retain investors at home for countries with excellent institutions and very lax environmental regulations. However, according to Figure 4, this latter case (Lack of corruption above 2 and EPS below 2) does not fit with any countries of our sample. Since countries with worse institutions (below 1) also have laxer environmental regulations (below 1.5), making their regulation slightly stricter would not affect relocation, unless they jump to the maximum level of stringency.

FIGURE 5

INTERACTION EFFECT OF LACK OF CORRUPTION AND EPS ON INWARD M\&AS

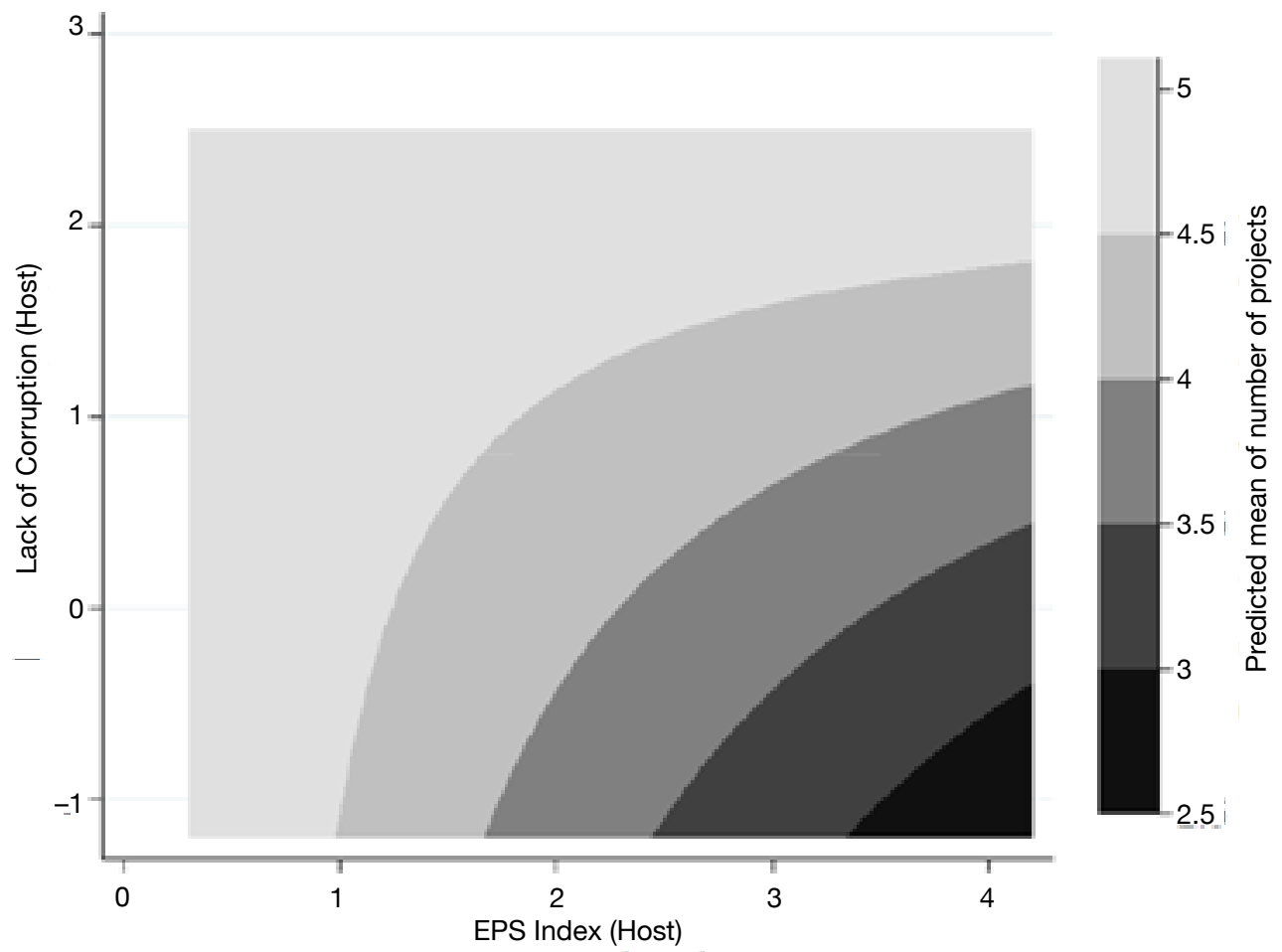

SOURCE: Authors' own elaboration based on Table 3's column 2 estimates. 


\section{FIGURE 6}

\section{INTERACTION EFFECT OF LACK OF CORRUPTION AND EPS INDEX ON OUTWARD M\&AS}

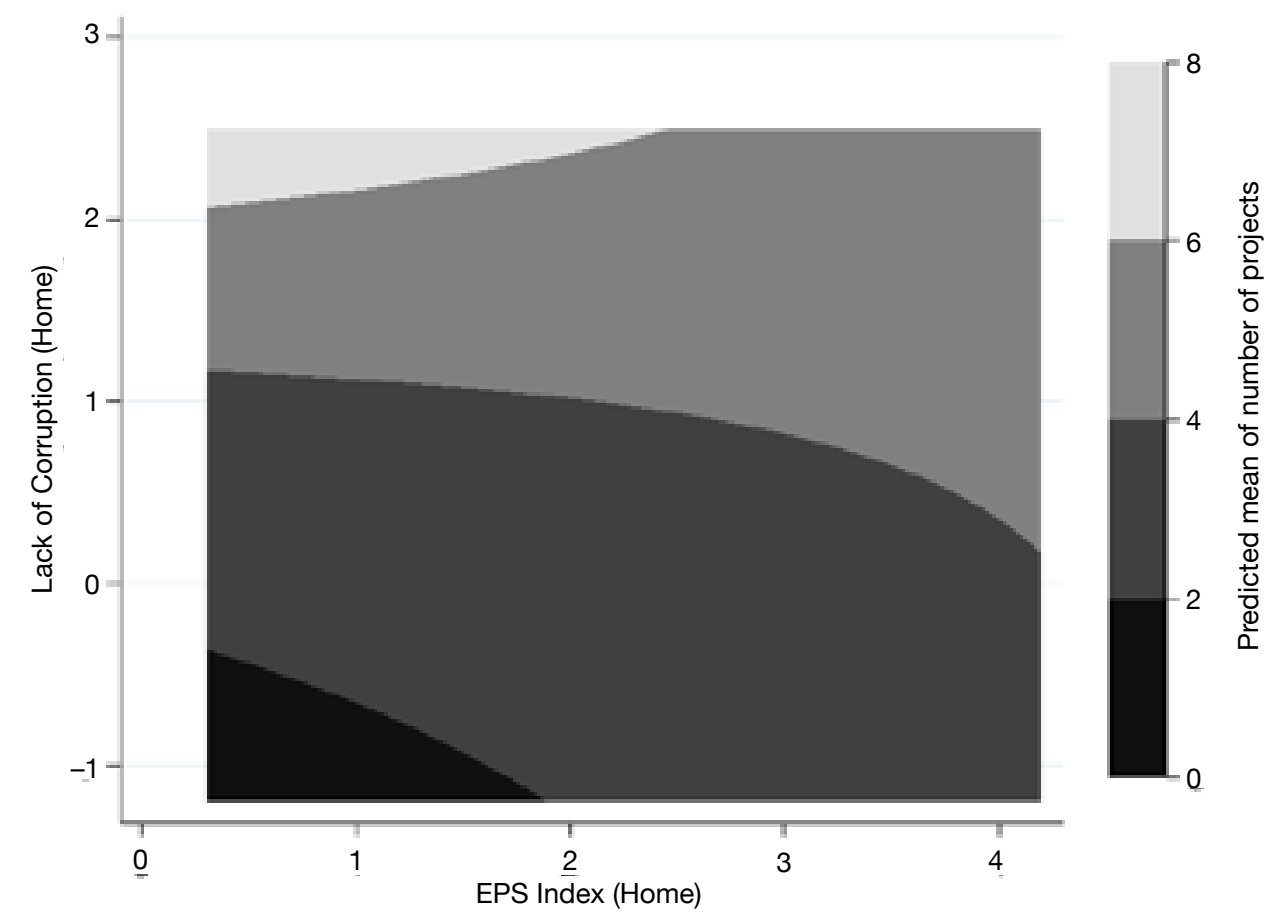

SOURCE: Authors' own elaboration based on Table 3's column 2 estimates.

\subsection{Robustness analysis}

Our sensitivity analysis seeks to address the potential endogeneity issues that might emerge if cross-border M\&As exert an influence on countries' environmental policies. To this end, we focus on sample 2, as it allows us to include the EPS Index, both of the MNEs' home and host country.

The first robustness analysis consists in lagging in $i$ periods the EPS Index $(i=1,2,3)$. As it can be gathered in Table 4, for host countries results confirm the previous results reported in Table 3. Increasing the EPS would negatively influence their capacity of attracting M\&As, but reducing corruption would limit this negative effect. From the MNEs' home country perspective, estimates confirm that increasing the EPS would not increase the number of cross-border M\&As realised by domestic firms oversea.

The second sensitivity analysis consists in using the Generalized Method of Moments (Arrelano \& Bond, 1991). We specify the EPS of home and host countries 
TABLE 4

SENSITIVITY ANALYSIS, EPS IN $t-i$

\begin{tabular}{|c|c|c|c|}
\hline & $\begin{array}{c}(1) \\
t-1\end{array}$ & $\begin{array}{c}(2) \\
t-2\end{array}$ & $\begin{array}{c}(3) \\
t-3\end{array}$ \\
\hline GDPsum & $\begin{array}{c}0.525^{* * * *} \\
(0.059)\end{array}$ & $\begin{array}{c}0.540^{* * * *} \\
(0.058)\end{array}$ & $\begin{array}{l}0.551^{* * * *} \\
(0.057)\end{array}$ \\
\hline Difference in GDPpc & $\begin{array}{l}0.139^{* *} \\
(0.058)\end{array}$ & $\begin{array}{l}0.133^{* *} \\
(0.057)\end{array}$ & $\begin{array}{l}0.132^{* *} \\
(0.056)\end{array}$ \\
\hline Exchange rate & $\begin{array}{l}-0.011 \\
(0.009)\end{array}$ & $\begin{array}{l}-0.012 \\
(0.009)\end{array}$ & $\begin{array}{l}-0.013 \\
(0.009)\end{array}$ \\
\hline Trade agreement & $\begin{array}{l}-0.003 \\
(0.090)\end{array}$ & $\begin{array}{l}-0.008 \\
(0.089)\end{array}$ & $\begin{array}{l}-0.011 \\
(0.087)\end{array}$ \\
\hline Investment agreement & $\begin{array}{c}0.419^{* * *} \\
(0.111)\end{array}$ & $\begin{array}{c}0.410^{* * * *} \\
(0.112)\end{array}$ & $\begin{array}{c}0.368^{* * * *} \\
(0.111)\end{array}$ \\
\hline Lack of corruption (home) & $\begin{array}{c}0.260^{* * * *} \\
(0.097)\end{array}$ & $\begin{array}{c}0.262^{* * * *} \\
(0.097)\end{array}$ & $\begin{array}{c}0.243^{* * * *} \\
(0.093)\end{array}$ \\
\hline Lack of corruption (host) & $\begin{array}{c}0.046 \\
(0.092)\end{array}$ & $\begin{array}{c}0.003 \\
(0.090)\end{array}$ & $\begin{array}{l}-0.055 \\
(0.089)\end{array}$ \\
\hline EPS (home) & $\begin{array}{c}0.052 \\
(0.035)\end{array}$ & $\begin{array}{c}0.031 \\
(0.036)\end{array}$ & $\begin{array}{l}-0.001 \\
(0.034)\end{array}$ \\
\hline × Lack of corruption (home) & $\begin{array}{c}-0.064^{* * *} \\
(0.019)\end{array}$ & $\begin{array}{c}-0.043^{* *} \\
(0.018) \\
\end{array}$ & $\begin{array}{l}-0.028 \\
(0.018)\end{array}$ \\
\hline EPS (host) & $\begin{array}{c}-0.170^{* * * *} \\
(0.046)\end{array}$ & $\begin{array}{c}-0.172^{* * * *} \\
(0.046)\end{array}$ & $\begin{array}{c}-0.165^{* * * *} \\
(0.044)\end{array}$ \\
\hline$\times$ Lack of corruption (host) & $\begin{array}{c}0.100^{* * *} \\
(0.024) \\
\end{array}$ & $\begin{array}{c}0.085^{* * * *} \\
(0.023) \\
\end{array}$ & $\begin{array}{c}0.071^{* * *} \\
(0.023) \\
\end{array}$ \\
\hline $\begin{array}{l}\text { Observations } \\
\text { Country FE } \\
\text { Country pair FE } \\
\text { Year FE } \\
\text { Pseudo R2 }\end{array}$ & $\begin{array}{c}17,424 \\
\\
X \\
X \\
0.830\end{array}$ & $\begin{array}{c}18,193 \\
X \\
X \\
0.828\end{array}$ & $\begin{array}{c}18,980 \\
X \\
X \\
0.826\end{array}$ \\
\hline
\end{tabular}

NOTE: PPML estimator. Robust standard error in parenthesis. ${ }^{*} p<0.10$, $* * p<0.05, * * * p<0.01$.

as endogenous and lag the dependent variable in two periods. In this way, we are able to accept the null hypothesis of no autocorrelation of order 2 . In addition, we estimate the model in two steps. It is important to highlight that in order to estimate this equation within the gravity model framework, we need to take the logarithm of the dependent variable. Due to the relevant presence of zeros usually present in a bilateral FDI database, we transform the number of projects in the following way: $\log$ (projects +1$)$. estimates are reported in Table 5. Overall, results corroborate those reported in Tables 3 and 4. 
TABLE 5

GENERALIZED METHOD OF MOMENTS

\begin{tabular}{|c|c|}
\hline & $\begin{array}{c}\text { Dependent variable } \\
\log (\text { projects }+1) \\
\text { (1) }\end{array}$ \\
\hline $\log ($ projects +1$), t-1$ & $\begin{array}{c}0.127 * * * \\
(0.017)\end{array}$ \\
\hline $\log ($ projctes +1$), t-2$ & $\begin{array}{c}0.057 * * * \\
(0.014)\end{array}$ \\
\hline GDPsum & $\begin{array}{c}0.104 * * * \\
(0.030)\end{array}$ \\
\hline Difference in GDPpc & $\begin{array}{c}0.079 * * \\
(0.031)\end{array}$ \\
\hline Bilateral exchange rate & $\begin{array}{l}-0.004 \\
(0.006)\end{array}$ \\
\hline Trade agreement & $\begin{array}{c}-0.097 * * * \\
(0.038)\end{array}$ \\
\hline Investment agreement & $\begin{array}{c}0.092 \\
(0.071)\end{array}$ \\
\hline Lack of corruption (host) & $\begin{array}{l}-0.032 \\
(0.063)\end{array}$ \\
\hline Lack of corruption (home) & $\begin{array}{l}-0.072 \\
(0.049)\end{array}$ \\
\hline Environmental Policy Stringency Index (home) & $\begin{array}{l}0.057 * \\
(0.032)\end{array}$ \\
\hline$\times$ Lack of corruption (home) & $\begin{array}{c}-0.063 * * * \\
(0.018)\end{array}$ \\
\hline Environmental Policy Stringency Index (host) & $\begin{array}{c}-0.111 * * * \\
(0.040)\end{array}$ \\
\hline × Lack of corruption (host) & $\begin{array}{c}0.073 * * * \\
(0.021)\end{array}$ \\
\hline Observations & 14,596 \\
\hline
\end{tabular}

NOTE: The dependent variable is the logarithm of number of projects plus one $(\log ($ projects +1$))$. Estimates include year fixed effects. The EPS Index in the home and host country is set as endogenous. Robust standard error in parenthesis. ${ }^{*} p<0.10$, ${ }^{*} p<0.05$, $* * * p<0.01$.

\section{Conclusions}

The present work is one of the few empirical tests of the PHH for a large sample of countries during a relatively long period of analysis (1995-2015). Moreover, the present work contributes to the literature by focusing on the case of cross-border M\&As, which is quite relevant considering that environmental policy can affect 
differently greenfield investment and M\&As, and since most FDI fly from and to developed countries and consist in M\&As.

Thanks to a rich bilateral dataset, we test the sensitivity of M\&As to environmental stringency taking into account the level of corruption. Unlike many studies, this allows us to test both the push and pull effects of the environmental regulation. All in all, the first part of the PHH (more stringent environmental policy would promote relocation of production abroad) is rejected. Only the second part of an extended PHH would be fully verified: MNE are more attracted by countries with more lenient environmental measures if the level of corruption is high. For countries in the median levels of corruption and EPS, MNEs face a trade-off between the compliance costs of environmental regulation and the corruption's costs. Then, M\&As could fly to countries with more stringent measures if corruption is reduced.

For instance, according to our results and based on the average levels of corruption and environmental stringency registered by Spain, ${ }^{12}$ all else equal, stricter environmental measures are unlikely to alter the existing patterns of outward M\&As. Regarding inward M\&A, a more stringent regulation would not lead to less incoming projects in this country. In turn, if these measures were to be accompanied by less corruption, the country could attract more M\&As.

The first part brings very good news. Our results mitigate the fears that more stringent environmental measures could lead to massive relocation of production through M\&As when the institutional context is taken into account. Then, fighting climate change through a stricter regulation could be efficient to the extent that it should not be associated with collateral costs in terms of relocation of polluting economic activity abroad. MNEs seem to internalise the "green strategy". The second part includes bad and good news. Countries that adopt stricter environmental policy could be less attractive in the eye of potential foreign acquirers of local firms, if their level of corruption is relatively high. Then, adopting "green" policies should be accompanied by fighting unappropriated behaviour in the institutional functioning that, undoubtedly would also have other positive outcomes for the economy.

Nevertheless, this study is not without limitations. Our study is a first step in accounting for heterogeneity among countries. However, the same environmental measures may not have the same effect on all industries and on all MNE (Lechner, 2018). There is obviously a huge unobserved heterogeneity among industries and firms. Furthermore, the literature stresses the need to account for agglomeration effects (Wagner \& Timmins, 2009) and geographic spillovers (Cheng et al., 2018; Millimet \& Roy, 2016). This is a common drawback in most studies dealing with FDI location, but also a path for future research.

12 During the period 1995-2015, Spain registers on average an indicator of Lack of corruption of 1.13 and EPS of 2.33. 


\section{References}

Adam, A., \& Filippaios, F. (2007). Foreign direct investment and civil liberties: A new perspective. European Journal of Political Economy, 23(4), 1038-1052.

Anderson, J. E. \& van Wincoop, E. (2003). Gravity with gravitas: A solution to the border puzzle. American Economic Review, 93(1), 170-192.

Antras, P., \& Yeaple, S. R. (2014). Multinational firms and the structure of international trade. In G. Gopinath, E. Helpman, \& K. Rogoff (Eds.), Handbook of international economics (pp. 55-130). Elsevier.

Baier, S. L., \& Bergstrand, J. H. (2009). Estimating the effects of free trade agreements on international trade flows using matching econometrics. Journal of International Economics, 77(1), 63-76.

Baumol, W. J., \& Oates W. E. (1988). The Theory of Environmental Policy. Cambridge Univ. Press. 2nd ed.

Bergstrand, J. H., \& Egger, P. (2013). What Determines BITs? Journal of International Economics, 90(1), 107-122.

Bialek, S., \& Weichenrieder, A. J. (2015). Environmental Regulation and Foreign Direct Investment: The Role of Mode of Entry. CESifo DICE Report, 13(4), 41-47. ifo Institut Leibniz-Institut für Wirtschaftsforschung an der Universität München, München.

Botta, E., \& Koźluk, T. (2014). Measuring Environmental Policy Stringency in OECD Countries: A Composite Index Approach (No. 1177). OECD Publishing. http://dx.doi. org/10.1787/5jxrjnc45gvg-en

Brucal, A., Javorcik, B., \& Love, I. (2019). Good for the environment, good for business: Foreign acquisitions and energy intensity. Journal of International Economics, 121, 103247.

Candau, F., \& Dienesch, E. (2017). Pollution haven and corruption paradise. Journal of Environmental Economics and Management, 85, 171-192.

Carril-Caccia, F., \& Pavlova, E. (2018). Foreign direct investment and its drivers: a global and EU perspective. ECB Economic Bulletin, 4, pp. 60-78.

Carril-Caccia, F., \& Pavlova, E. (2020). Mergers and acquisitions \& trade: A global value chain analysis. The World Economy, 43(3), 586-614.

Chen, V. Z., Li, J., \& Shapiro, D. M. (2015). Subnational institutions and outward FDI by Chinese firms: The mediating role of firm-specific advantages. Multinational Business Review, 23(4), 254-276.

Cheng, Z., Li, L., \& Liu, J. (2018). The spatial correlation and interaction between environmental regulation and foreign direct investment. Journal of Regulatory Economics, 54(2), 124-146.

Cole, M. A., Elliott, R. J., \& Zhang, L. (2017). Foreign direct investment and the environment. Annual Review of Environment and Resources, 42, 465-487.

Contractor, F. J., Dangol, R., Nuruzzaman, N., \& Raghunath, S. (2020). How do country regulations and business environment impact foreign direct investment (FDI) inflows? International Business Review, 29(2). http://doi.org/10.1016/j.ibusrev.2019.101640

Cuadros, A., Martín-Montaner, J., \& Paniagua, J. (2016). Homeward bound FDI: Are migrants a bridge over troubled finance? Economic Modelling, 58, 454-465.

Dam, L., \& Scholtens, B. (2008). Environmental regulation and MNEs location: Does CSR matter? Ecological Economics, 67(1), 55-65. 
di Giovanni, J. (2005). What drives capital flows? the case of cross-border M\&A activity and financial deepening. Journal of International Economics, 65(1), 127-149.

Dijkstra, B. R., Mathew,A.J., \& Mukherjee A. (2011). Environmental regulation: an incentive for foreign direct investment. Review of International Economics, 19(3), 568-78

Egger, P., \& Winner, H. (2005). Evidence on corruption as an incentive for foreign direct investment. European Journal of Political Economy, 21(4), 932-952.

Ekholm, K., Forslid, R., \& Markusen, J.R. (2007). Export-platform foreign direct investment. Journal of the European Economic Association, 5(4), 776-795.

Elliott, R. J. R., \& Zhou, Y. (2013). Environmental regulation induced foreign direct investment. Environmental and Resource Economics, 55(1), 141-158

Erel, I., Liao, R. C., \& Weisbach, M. S. (2012). Determinants of cross-border mergers and acquisitions. The Journal of Finance, 67(3), 1045-1082.

Fredriksson,P.G.,List, J.A., \& Millimet,D.L.(2003). Bureaucratic corruption, environmental policy and inbound US FDI: theory and evidence. Journal of public Economics, 87(7-8), 1407-1430.

Gallagher, K. P., \& Zarsky, L. (2007). The enclave economy: foreign investment and sustainable development in Mexico's Silicon Valley. Mit Press.

Garsous, G., \& Kozluk, T. (2017). Foreign Direct Investment and The Pollution Haven Hypothesis (No. 1379). OECD Publishing. https://doi.org/10.1787/18151973

Hanna, R. (2010). US environmental regulation and FDI: evidence from a panel of US-based multinational firms. American Economic Journal: Applied Economics, 2(3), 158-89.

Hanson, G. H., Mataloni, R. J., \& Slaughter, M. J. (2005). Vertical production networks in multinational firms. Review of Economics and Statistics, 87(4), 664-678.

Head, K., \& Ries, J. (2008). FDI as an outcome of the market for corporate control: Theory and evidence. Journal of International Economics, 74(1), 2-20.

Head, K., Mayer, T., \& Ries, J. (2010). The erosion of colonial trade linkages after independence. Journal of International Economics, 81(1), 1-14.

Hofmann, C., Osnago, A., \& Ruta, M. (2017). Horizontal depth: a new database on the content of preferential trade agreements (WPS No 7981). TheWorld Bank.

Horstmann, I. J., \& Markusen, J. R. (1987). Strategic investments and the development of multinationals. International Economic Review, 109-121.

Jang, Y. J. (2011). The impact of bilateral free trade agreements on bilateral foreign direct investment among developed countries. The World Economy, 34(9), 1628-1651.

Javorcik, B. S., \& Wei, S.-J. (2003). Pollution Havens and Foreign Direct Investment: Dirty Secret or Popular Myth? Contributions in Economic Analysis \& Policy, 3(2). https://doi. org/10.2202/1538-0645.1244

Javorcik, B. S., Özden, Ç., Spatareanu, M., \& Neagu, C. (2011). Migrant networks and foreign direct investment. Journal of Development Economics, 94(2), 231-241.

Jin, J., Du, J., Long, X., \& Boamah, K. B. (2019). Positive mechanism of foreign direct investment enterprises on China's environment: Analysis of host country regulation and parent company management. Journal of Cleaner Production, 227, 207-217.

Kahouli, B., \& Omri, A. (2017). Foreign direct investment, foreign trade and environment: New evidence from simultaneous-equation system of gravity models. Research in International Business and Finance, 42, 353-364.

Kaufmann, D., Kraay, A., \& Mastruzzi, M. (2011). The Worldwide Governance Indicators: Methodology and Analytical Issues. Hague Journal on the Rule of Law, 3(2), 220-246. 
Krautheim, S. (2013). Export-supporting FDI. Canadian Journal of Economics/Revue Canadienne D'economique, 46(4), 1571-1605.

Leon-Gonzalez, R., \& Tole, L. (2015). The Determinants of Mergers \& Acquisitions in a Resource-Based Industry: What Role for Environmental Sustainability? Review of Economic Analysis, 7(2), 111-134.

Markusen, J. R., Morey, E. R., \& Olewiler, N. D. (1993). Environmental policy when market structure and plant locations are endogenous. Journal of Environmental Economics and Management, 24(1), 69-86.

Martinez-Galan, E., \& Fontoura, M. P. (2019). Global value chains and inward foreign direct investment in the 2000s. The World Economy, 42(1), 175-196.

Martínez-Zarzoso, I., \& Oueslati, W. (2018). Do deep and comprehensive regional trade agreements help in reducing air pollution? International Environmental Agreements: Politics, Law and Economics, 18(6), 743-777.

Mavisakalyan, A., \& Tarverdi, Y. (2019). Gender and climate change: Do female parliamentarians make difference? European Journal of Political Economy, 56, 151-164.

Millimet, D. L., \& Roy, J. (2016). Empirical tests of the pollution haven hypothesis when environmental regulation is endogenous. Journal of Applied Econometrics, 31(4), 652677.

Nocke, V., \& Yeaple, S. (2007). Cross-border mergers and acquisitions vs. greenfield foreign direct investment: The role of firm heterogeneity. Journal of International Economics, 72(2), 336-365.

Nuñez-Rocha, T., \& Martínez-Zarzoso, I. (2019). Are international environmental policies effective? The case of the Rotterdam and the Stockholm Conventions. Economic Modelling, 81, 480-502.

Paniagua, J., \& Sapena, J. (2014). Is FDI doing good? A golden rule for FDI ethics. Journal of Business Research, 67(5), 807-812.

Pearson CS. (1987). Multinational Corporations, Environment, and the Third World: Business Matters. Duke University Press.

Poelhekke, S., \& Van der Ploeg, F. (2015). Green havens and pollution havens. The World Economy, 38(7), 1159-1178.

Rivera, J., \& Oh, C. H. (2013). Environmental regulations and multinational corporations' foreign market entry investments. Policy Studies Journal, 41(2), 243-272.

Rossi, S., \& Volpin, P. F. (2004). Cross-country determinants of mergers and acquisitions. Journal of Financial Economics, 74(2), 277-304.

Sanna-Randaccio, F., \& Sestini, R. (2012). The impact of unilateral climate policy with endogenous plant location and market size asymmetry. Review of International Economics, 20(3), 580-599.

Santos-Silva, J., \& Tenreyro, S. (2006). The log of gravity. The Review of Economics and Statistics, 88(4), 641-658.

Tang,J.(2015). Testing the pollution haven effect: does the type of FDI matter? Environmental and Resource Economics, 60(4), 549-578.

UNCTAD (2020). International Investment Agreements Navigator. https://investmentpolicy. unctad.org/international-investment-agreements/

United Nations, Department of Economic and Social Affairs, Population Division (2017). Trends in International Migrant Stock: The 2017 Revision. United Nations database (POP/DB/MIG/Stock/Rev.2017). 
Wagner, U. J., \& Timmins, C. D. (2009). Agglomeration effects in foreign direct investment and the pollution haven hypothesis. Environmental and Resource Economics, 43(2), 231256.

Wang, H., Dong, C., \& Liu, Y. (2019). Beijing direct investment to its neighbors: A pollution haven or pollution halo effect? Journal of Cleaner Production, 239, 118062.

Wang, Y., Cheng, L., Wang, H., \& Li, L. (2014). Institutional quality, financial development and OFDI. Pacific Science Review, 16(2), 127-132.

Wang, Y., Sun, X., \& Guo, X. (2019). Environmental regulation and green productivity growth: Empirical evidence on the Porter Hypothesis from OECD industrial sectors. Energy Policy, 132, 611-619.

Wei, S. J. (2000). How taxing is corruption on international investors? Review of Economics and Statistics, 82(1), 1-11.

Xing, Y., \& Kolstad, C. D. (2002). Do lax environmental regulations attract foreign investment? Environmental and Resource Economics, 21(1), 1-22.

Zugravu-Soilita, N. (2017). How does foreign direct investment affect pollution? Toward a better understanding of the direct and conditional effects. Environmental and Resource Economics, 66(2), 293-338. 


\section{APPENDIX}

TABLE A

COUNTRY SAMPLE

\begin{tabular}{|llll|}
\hline Argentina & Egypt & Liechtenstein & Saudi Arabia \\
Australia & Estonia & Lithuania & Serbia \\
Austria & Finland & Luxembourg & Seychelles \\
Bahamas & France & Macedonia & Singapore \\
Bahrain & Georgia & Malaysia & Slovakia \\
Belarus & Germany & Malta & Slovenia \\
Belgium & Ghana & Mauritius & South Africa \\
Bermuda & Greece & Mexico & South Korea \\
Bolivia & Guatemala & Morocco & Spain \\
Bosnia and Herzegovina & Hong Kong & Namibia & Sri Lanka \\
Botswana & Hungary & Netherlands & Sweden \\
Brazil & Iceland & New Zealand & Switzerland \\
Bulgaria & India & Nigeria & Thailand \\
Canada & Indonesia & Norway & Trinidad and Tobago \\
Cayman Islands & Ireland & Oman & Tunisia \\
Chile & Israel & Pakistan & Turkey \\
China & Italy & Panama & Ukraine \\
Colombia & Jamaica & Papua New Guinea & United Arab Emirates \\
Costa Rica & Japan & Peru & United Kingdom \\
Croatia & Jordan & Philippines & United States \\
Cyprus & Kazakhstan & Poland & Uruguay \\
Czech Republic & Kenya & Portugal & Venezuela \\
Denmark & Kuwait & Puerto Rico & Vietnam \\
Dominican Republic & Latvia & Qatar & Zambia \\
Ecuador & Lebanon & Russia & Zimbabwe \\
\hline
\end{tabular}

NOTE: Countries in bold are those for which the OECD's EPS Index is available. These 34 countries are the ones that conform the restricted sample with 34 home and host countries.

SOURCE: Authors' own elaboration. 